\title{
Note \\ K VALUES OF SOILS OF U.S. VIRGIN ISLANDS
}

\author{
Miguel A. Lugo-López and David Sotomayor-Ramirez ${ }^{3}$ \\ J. Agric. Univ. P.R. 84(3-4):185-187 (2000)
}

The $\mathrm{K}$ factor is one of six criteria used in the Universal Soil Loss Equation (USLE) (Wischmeiex; 1971; Wischmeier and Smith, 1961) for predicting annual mean soil losses by sheet and rill erosion from selected land areas. The equation is as follows: $A=$ $R * \mathrm{~K} L \mathrm{~L}$ \% , where $A$ is the calculated mean annual soil loss per unit area, $R$ is the rainfall-runoff erosivity factor, $\mathrm{K}$ is the soil erodibility factor, $\mathrm{LS}$ is the slope length and slope steepness factor, $\mathrm{C}$ is the cover and management factor, and $\mathrm{P}$ is the practice factor due to the type of cultivation practices (Miller and Gardiner, 1998). A revised version of the USLE known as the RUSLE has been implemented with a computer program, and modifications are described in Renard et al. (1991). The two models are conceptually similar and use the same factors although RUSLE includes a seasonally variable $\mathrm{K}$ value due to freeze-thaw events, soil moisture and compaction. The USLE is a useful tool, easy to understand, and still in use in some parts of the world.

Although knowledge about the other factors is required to properly assess erosion hazards, the $\mathrm{K}$ factor may be of greater importance from a sensitivity point of view than the $\mathrm{R}$ factor because of the great range in $\mathrm{K}$ values (Renard et al., 1991). Factors influencing $\mathrm{K}$ values include particle size distribution, organic matter level, aggregate stability, and soil structure and permeability. High-sand and high-clay content soils tend to have lower $\mathrm{K}$ values; high-silt content soils, higher $\mathrm{K}$ values. Organic matter, larger structural aggregates, and rapid soil permeability all reduce the $K$ factor. Values range from 1.0 (most easily eroded) to 0.01 (least easily eroded), with most soils having $\mathrm{K}$ values between 0.10 and 0.50 .

In a recent publication of the USDA Natural Resources Conservation Service, the soil erodibility factor, $\mathrm{K}$, is listed for corresponding soil series within soil map units (Davis and Santiago, 1998). Although it is best to use $K$ values at the series level, the site specific $\mathrm{K}$ value can be quite different from the $\mathrm{K}$ value given in soil survey information. Given inherent limitations, the data summarized in this paper by orders of soil taxonomy might be useful in planning land use programs in other areas where the USLE is still in use, and where insufficient basic data at the soil series level are available to estimate $\mathrm{K}$.

The 23 series identified were classified into 23 soil families belonging to six soil orders: Alfisols, Entisols, Histosols, Inceptisols, Mollisols and Vertisols (Lugo-López et al., 1998). In order to account for the non-uniform area of the varying soils, the ratio of the series to the total area occupied by the soil order was used as a weighting factor to be applied for the calculation of the mean value. The $K$ values herein reported of individual series range from 0.02 to 0.32 , and weighted means are summarized in Table 1.

'Manuscript submitted to Editorial Board 26 April 1999.

2Professor Emeritus and Consultant, College of Agricultural Sciences, UPR-Mayagüez Campus.

"Associate Professor, Agronomy and Soils Dept., College of Agricultural Sciences, UPR-Mayagüez Campus, P.O. Box 9030, Mayagüez, PR 00681-9030. 
TABLE 1.--Weighted mean K values for soil orders of the U.S. Virgin Islands.

\begin{tabular}{lc}
\hline Order & Mean K value \\
\hline Alfisols & 0.15 \\
Entisols & 0.14 \\
Histosols & 0.20 \\
Inceptisols & 0.16 \\
Mollisols & 0.09 \\
Vertisols & 0.28 \\
\hline
\end{tabular}

The 13 Mollisols of the U.S. Virgin Islands are the least susceptible to erosion with a mean $K$ value of 0.09 . Individual $K$ values range from 0.05 to 0.1 in soils of the series Annaberg, Arawak, Cramer, Hesselberg, Sion, Fredriksdal, Jealousy, and Susannaberg; and from 0.11 to 0.20 in soils of the series Parasol, Cinnamon Bay, Glynn and Maho Bay. Only one-Carib-has an unexpectedly high $\mathrm{K}$ value, but the relative area occupied by this soil is extremely small $(<0.5 \%)$. The $K$ values in three of four soils in the Entisols are smaller than 0.10; however, the corresponding value for the other series (Sandy Point is a poorly drained soil of unvegetated saline marshes and flats) is 0.20 and occupies a relatively large extent of the area $(55 \%)$. The mean $K$ value for the Entisols is 0.14 . Inceptisols range in $\mathrm{K}$ values from 0.15 to 0.20 with a mean value of 0.16 . The $\mathrm{K}$ values reported for Entisols and Inceptisols are in agreement with data from other investigators reporting $\mathrm{K}$ values of the same magnitude in Hawaii (El-Swaify and Dangler, 1977), Puerto Rico (Lugo-López and Acevedo, 1982) and Haití (Reynolds et al., 1985). Only one Alfisol and one Vertisol were identified; their corresponding $K$ values were 0.15 and 0.28 , respectively. As in Puerto Rico, the Vertisols of the U.S. Virgin Islands have the highest potential for erosion (Lugo-López and Acevedo, 1982), when only the $\mathrm{K}$ factor is considered.

This grouping of $\mathrm{K}$ values according to soil orders in combination with other parameters from USLE can guide engineers, agronomists, and farmers as to the most judicious use of soil resources for land planning and soil management when values for individual soil series are not available.

\section{LITERATURE CITED}

Davis, J. R. and C. L. Santiago, 1998. Soil Survey of the U.S. Virgin Islands. USDA NaturaI Resources Conserv. Service. Interim Document.

El-Swaify, S. A. and E. W. Dangler, 1977. Erodibilities of selected tropical soils in relation to structural and hydrologic parameters. Proc. Int. Conf. Soil Erosion. West Lafayette, IN. pp. 127-134.

Lugo-López, M. A. and G. Acevedo, 1982. K values of the soils of Puerto Rico. J. Agric. Univ. P. R. 66(4):311-312.

Lugo-López, M.A., F. H. Beinroth, C. L. Santiago and G. R. Brannon, 1998. Updated taxonomic classification of the soils of the U.S. Virgin Islands, 1997. Agric. Exp. Sta. Bull, 297.

Miller, R. W. and D. T. Gardiner, 1998. Soils in our environment. $8^{\text {th }}$ ed. Prentice Hall, Upper Saddle River, $\mathrm{NJ}$.

Renard K. G., G. R. Foster, G.A. Weesies and J. P. Porter, 1991. RUSLE. Revised Universal Soil Loss Equation. J. Soil Water Conserv. 46:30-33. 
Reynolds, C. A., A. Wahab and M. A. Lugo-López, 1985. K values of the soils of the Acul Watershed in Haití. J. Agric. Univ. P. R. 69(3):441-443.

Wischmeier, W. H., 1971. The erosion equation. A tool for conservation planning. Proc. 26 Ann. Meeting Soil Conserv. Soc., Ankeni, IA, pp. 73-78.

Wischmeier, W. H. and D. D. Smith, 1961. A universal soil-loss estimating equation to guide conservation farm planning. Trans 7th Cong. Intl. Soil Sci. Soc. 1:418-425. 